Iğdır Üniversitesi Fen Bilimleri Enstitüsü Dergisi, 11(3): 1781-1791, 2021

Araştırma Makalesi / Research Article

Geliş tarihi / Received: 04-02-2021

Kabul tarihi / Accepted: 29-03-2021

To Cite: Açar M, Beker Akbulut G, Taşar N, 2021. Anatomical, Palynological and Biochemical Studies on Gundelia dersim Vitek, Yüce \& Ergin (Asteraceae) an Endemic of Turkey. Journal of the Institute of Science and Technology, 11(2): 17811791.

\title{
Anatomical, Palynological and Biochemical Studies on Gundelia dersim Vitek, Yüce \& Ergin (Asteraceae) an Endemic of Turkey
}

\section{Mikail AÇAR $^{1 *}$, Gülçin BEKER AKBULUT ${ }^{2}$, Neslihan TAŞAR ${ }^{1}$}

\begin{abstract}
The Asteraceae family is the largest in the plant kingdom in the world. Gundelia is a genus that belongs to this family and is commonly referred to as the kenger name in Anatolia. Gundelia dersim is also an endemic species defined from Eastern Anatolia. In this study, anatomical, palynological and biochemical properties of G. dersim were discussed. When the anatomical structure of $G$. dersim was examined, it was seen that the mesophyll type, in which the midrib of the leaf was developed, was unifacial. There are too many sclerenchymatic cells in the vascular bundles. In addition, laticifer elements were seen on the stem and leaf. Also, it was observed that the pollen of the species is in echinate ornamentation and pollen grains are radial symmetrical, isopolar, tricolporate. Following biochemical analysis, pigment analysis, total carbohydrate and lipid peroxidation were performed. The chlorophyll a and chlorophyll $\mathrm{b}$ content of the species in both stem and leaf were analyzed, and the most chlorophyll content was found in the leaf. With this research, for the first time, a detailed anatomical investigation was conducted on the genus Gundelia, and it is a current view with the first consideration of the anatomical, palynological and biochemical aspects of G. dersim.
\end{abstract}

Keywords: Chlorophyll, Compositae, endemic, pigment, pollen.

${ }^{1}$ Mikail AÇAR (Orcid ID: 0000-0003-3848-5798), Munzur Üniversitesi, Tunceli Meslek Yüksekokulu, Bitkisel ve Hayvansal Üretim Bölümü, Tunceli 62000, Türkiye

${ }^{2}$ Gülçin Beker AKBULUT (Orcid ID: 0000-0003-3529-5999), Malatya Turgut Özal Üniversitesi/Battalgazi Meslek Yüksekokulu/Park ve Bahçe Bitkileri Bölümü/Peyzaj ve Süs Bitkileri, Malatya, Türkiye

${ }^{1}$ Neslihan TAŞAR (Orcid ID: 0000-0002-0417-4660), Munzur Üniversitesi, Tunceli Meslek Yüksekokulu, Bitkisel ve Hayvansal Üretim Bölümü, Tunceli 62000, Türkiye

*Sorumlu Yazar/Corresponding Author: Mikail AÇAR, e-mail: mikailacar27@ hotmail.com

The article was presented as a poster at the "1st International Congress on Plant Biology, IConPB 2018" symposium organized in Konya in 2018. 


\section{INTRODUCTION}

Asteraceae (Compositae) is a family with the most taxa in the world. This family contains many genera. Taxa belong to the family containing 24.000-30.000 species and 1600-1700 genera spread on all continents except Antarctica. Although there are original estimates, it is assumed that there are 200,000300,000 flowering plant species, and one of every 8-12 flowering plant species belongs to the Asteraceae family (approximately 10\%) (Funk et al., 2005).

One of these genera is the Gundelia L. genus, which has many species in our country. It was known that the genus Gundelia was represented by a single species until the 2000s. However, in recent years, many new species have been identified; The new described species Gundelia aragatsi Vitek, Fayvush, Tamanyan \& Gemeinholzer (Vitek et al., 2010), Gundelia armeniaca (Nersesian, 2014) from Armenia, Gundelia dersim Vitek, Yüce \& Ergin (Vitek et al., 2014), Gundelia munzuriensis Vitek, Yüce and Ergin (Vitek et al., 2014), Gundelia vitekii Armağan (Armağan, 2016), Gundelia komagenensis Furat (Fırat, 2016a), Gundelia colemerikensis Frat (F1rat, 2016a), Gundelia cilicica F1rat (F1rat, 2016a), Gundelia anatolica Frrat (F1rat, 2016a), Gundelia mesopotamica F1rat (2017a) and Gundelia siirtica Firat (2019a), Gundelia cappadocica Firat (Firat, 2021b) from Turkey, Gundelia tehranica Vitek and Noroozi (Vitek and Noroozi, 2017) from Iran. Moreover, added new record for the flora of Turkey Gundelia rosea M.Hossain \& Al-Taey (Frrat, 2017b), Gundelia armeniaca Nersesyan (F1rat, 2018a), Gundelia purpurascens (Bornm.) Firat (Frrat, 2018a). The resurrection and a new status of Gundelia asperrima (Trautv.) Firat (Firat, 2017c), Gundelia armata (Freyn \& Sint.) Firat (Frrat, 2019b).

Karyotype data for 12 taxa are reported in Genç and Firat (2019). According to molecular dating, the distinction of the genus Gundelia from the relative genera was around 14.1 million years ago (mya) (Tarikahya Hacioğlu and Firat, 2017). The recent taxonomical studies based on morphological data and ITS based molecular data suggested that the genus Gundelia L. (Asteraceae) should be divided into two subgenera; Gundelia L. subg. Gundelia (Type species: G. tournefortii) and Gundelia L. subg. Anatolia Frrat subg. nov. (Type species: G. anatolica). Additionally, morphological data suggest that there should be two sections within the subgenus Gundelia; Gundelia L. subg. Gundelia sect. Gundelia (Type species: G. tournefortii) and Gundelia L. subg. Gundelia sect. Komagenenses Frat sect. nov. (Type species: G. komagenensis) (Frrat, 2021).

Gundelia genus classification is taxonomically difficult because of its macro and micromorphological characteristics. So, it is defined as the 'rogue' genus (Wortley et al., 2007). Gundelia genus is represented by 19 taxa in Anatolia (Frrat, 2021b); and the total number of species in Gundelia increased to twenty-two and two sections (F1rat, 2021a,b). Most of these species are endemic to Turkey. Gundelia species in Anatolia; Kênger, Qorav, Kereng, Kerenk, Keven, Kengel, Has kanger, Ac1 kenger, Eşek dikeni, Kenger are known by vernacular names (Fırat, 2013). Gundelia dersim Vitek, Yüce \& Ergin is often called 'Kereng' and 'Kenger'. Milky secretion, like a chewed gum between people in the Tunceli region of Turkey (Çakılcıoğlu, 2020). In our meetings with the local people, this milklike secretion is used in ice cream making and gastric disorders such as gastritis, ear disorders, jaw strengthening and chewing problems. General morphological features are as follows; Stout perennial herb with milky latex. Leaves alternate, pinnatisect, strongly spiny-dentate, uppermost is usually involucrate. Capitula few-flowered, morphologically homogamous and discoid, densely aggregated into Eryngium L.-like heads (pseudocephalia) (Kupicha, 1975). G. dersim is a new endemic species described from Eastern Anatolia (Vitek et al., 2014). The spreading area of this species is like G. glabra Mill., G. munzuriensis Vitek, Yüce \& Ergin, G. tournefortii L., G. armata (Freyn \& Sint.) Frrat and G. vitekii 
Armağan. Thus, studies on these species are essential in terms of the taxonomic and ecological conditions of the genus Gundelia.

Anatomical and palynological studies can support morphological features and provide valuable characters for taxonomic studies. Biochemical studies are very important in terms of the relationship of species to ecological environments. At the same time, it can provide important contributions to reveal the biochemical similarities and differences between taxa close together (Karaaslan et al., 2014; Konak et al., 2017; Afrasiabi et al., 2019).

There is no current anatomical study on the Gundelia genus. A preliminary study of Solereder and Scott (1908) and Metcalfe and Chalk (1950) on the genus and a detailed study has not been found later. The genus Gundelia was represented by a single species until recent years. However, the number of species has increased due to the studies carried out in recent years. Therefore, studies to be carried out are becoming necessary.

No studies on the anatomical, palynological and biochemical content of $G$. dersim have been found. Therefore, this study aims to examine the characteristics of G. dersim in this respect.

\section{MATERIALS AND METHODS}

\section{Plant material}

The main material of this investigation is Gundelia dersim (Figure 1) collected from between B7, Tunceli (Turkey), Ovacık-Koyungölü (1280m)(Tunceli province) riverside and Aktuluk district $(1000 \mathrm{~m})$ (Tunceli centre) region in June and at the time of flowering. Map of Turkey (Frrat, 2016b) and map of detail of the area (Google map, 2021). In the samples collected, the homogeneity of the population was taken into consideration. Herbarium material(Voucher specimen no: MA 2003) is stored at Munzur University.
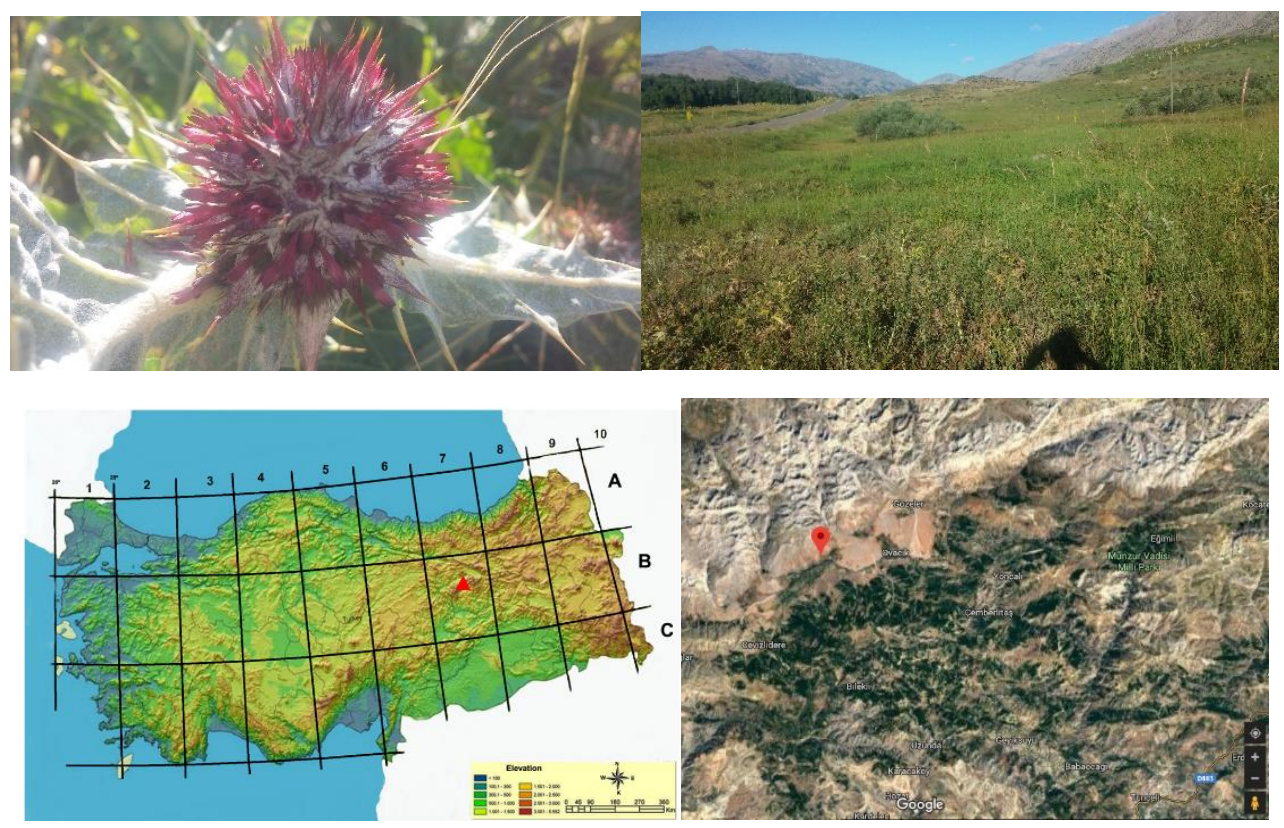

Figure 1. Synflorescence view, habitat and collection area of G. dersim

\section{Anatomical analysis}

By collecting $G$. dersim from its natural habitats, the plant parts were preserved in $70 \%$ alcohol used in anatomical studies. Sectioning operations were performed manually with the help of razors. It is stained with sartur reagent and safranin to distinguish between tissues and cells (Baytop, 1972; Algan, 
1981). Anatomical observations were made and photographed using the Olympus BX53 light microscope.

\section{Palynological analysis}

For the purpose of studying pollen grains in Gundelia, specimens were collected in their flowering period. A minimum of ten samples of species has been examined. Palynological studies were carried out in SEM at Munzur University. The terminology used is mainly based on that recommended by Punt et al. (2007).

\section{Biochemical analysis}

Also, the material to be used for biochemical studies was stored at $-80^{\circ} \mathrm{C}$. Following biochemical analysis, pigment analysis, total carbohydrate and lipid peroxidation were performed.

\section{Measurement of total carbohydrate content}

The total content of carbohydrate was measured according to the method proposed by Rosenberg (1980). Leaf and stem samples were cut into small pieces and kept at $50{ }^{\circ} \mathrm{C}$ for 1 day. Then, it was ground in the blender and left again at $50{ }^{\circ} \mathrm{C}$ for 1 night. Samples were taken to the desiccator after 24 hours, waiting for 1 hour, weighing $0.2 \mathrm{~g}$ from the samples, $5 \mathrm{~mL}$ of $72 \% \mathrm{H}_{2} \mathrm{SO}_{4}$ was added and hydrolysis for 3 hours with mixing every 15 minutes. Then $45 \mathrm{~mL}$ of distilled water was added and kept in the refrigerator for 1 night. Samples were filtered from filter papers after 24 hours. After the filtrate was diluted $1 / 100,2 \mathrm{~mL}$ of an antron reagent prepared daily was added to $500 \mu \mathrm{L}$ and mixed rapidly in the vortex. This mixture was put in tubes, and their mouths were closed with aluminium foil. The tubes were kept in a boiling water bath for 10 minutes and then read against the control in $620 \mathrm{~nm}$ wavelength spectrophotometer (Shimadzu UV-1201V) by performing the same procedures with distilled water. Glucose values were calculated in response to the standard values entered the Slide program.

\section{Photosynthetic pigment analysis}

De Kok and Graham method was used for the extraction of pigments (De-Kok and Graham, 1980). For extraction, 1 gram of each of the leaf and stem samples ground in the blender was taken in 3 replicates for each sample and placed in $50 \mathrm{ml}$ of acetone (100\% Merck) in a glass mortar and homogenized. Then the flasks were placed with aluminium foil in such a way that they would not see them, and the mouths of the flasks were closed with parafilm. It was homogenized for 30 minutes in a shaking oven. These samples were then kept in the refrigerator set at $4{ }^{\circ} \mathrm{C}$ for 24 hours. Samples taken out of the refrigerator were filtered and $1 / 5$ water was added. These samples were re-homogenized for 15 minutes in a shaking oven and then kept in the refrigerator for 24 hours. Samples were centrifuged after 24 hours at $3000 \mathrm{rpm}$ for 10 minutes. The absorbance values of the centrifuged samples were read at 662, 645, $470 \mathrm{~nm}$ according to Lichtenthaler and Welburn (1983) and the two most important types of chlorophyll in terms of photosynthesis are chlorophyll a, chlorophyll b and carotenoid and total chlorophyll contents were calculated.

\section{Lipid peroxidation analysis}

The method was made according to Heath and Packer (1968). $0.5 \mathrm{~g}$ of fresh leaf tissue was homogenized in $5 \mathrm{~mL}$ of $0.1 \%$ TCA. The homogenate was centrifuged at $10.000 \mathrm{~g}$ for 10 minutes. $2 \mathrm{~mL}$ of this solution was kept in a water bath at $95^{\circ} \mathrm{C}$ for 30 minutes with $2 \mathrm{~mL}$ of $0.5 \%$ TBA (prepared in $20 \%$ TCA). At the end of the period, the samples were placed on ice. It was then centrifuged at 10.000 $\mathrm{g}$ for 15 minutes. The absorbance of the supernatant was measured at $532 \mathrm{~nm}$ and $600 \mathrm{~nm}$, and 
Anatomical, Palynological and Biochemical Studies on Gundelia dersim Vitek, Yüce \& Ergin (Asteraceae) an Endemic of Turkey

measurements at $600 \mathrm{~nm}$ were confirmed by subtracting the measurements at $532 \mathrm{~nm}$. The amount of MDA was calculated with $155 \mathrm{mM}-1 \mathrm{~cm}-1$ extinction coefficient.

\section{RESULTS AND DISCUSSION}

\section{Anatomical results}

The stem has a single-layered epidermis. Under the epidermis is the cortex layer. There is a collenchymatic hypodermis with 1- 2 layers of thickened walls at the top of the cortex and 4- 6 layers of sclerenchyma tissue below it. This sclerenchymatic layer surrounds the stem. Under the sclerenchyma is the parenchyma tissue. It is seen in cortical vascular bundles within the parenchyma tissue mentioned. The stem has numerous annularly arranged by vascular bundles. These bundles are as follows: phloem surrounded by a scleranchymatic layer and xylem under phloem, and it a scleranchymatic layer. Among the vascular bundles are interfascicular cells. The stem's inner part is made up of parenchymatic pith cells, and in the centre is its pith cavity. Leaf epidermis anticline wall is flat. Although stoma is anomocytic, anisocytic type is also rarely seen on the upper surface. It is amphistomatic according to the surface with stomata on the leaf. Leaf mesophyll type is unifacial. Mesophyll consisted of 8-9 layers of palisade cells. The midrib of the leaf is very developed and contains many vascular bundles. A single layer epidermis is covered with a cuticle on the outermost, a collenchymatic hypodermis sometimes 12 layers below, just below the hypodermis lignified scleranchymatic layer surrounding the midrib. There is a parenchymatic region comprising round cells that fill the interior and surround the vascular bundles. Vascular bundles are surrounded by a scleranchymatic layer, then xylem, phloem, and again a scleranchymatic layer. The conduction bundle is in the form of a collateral bundle. There are secretions in the parenchyma cells. Also, infrequently, laticifer elements have been observed (Figure 2).

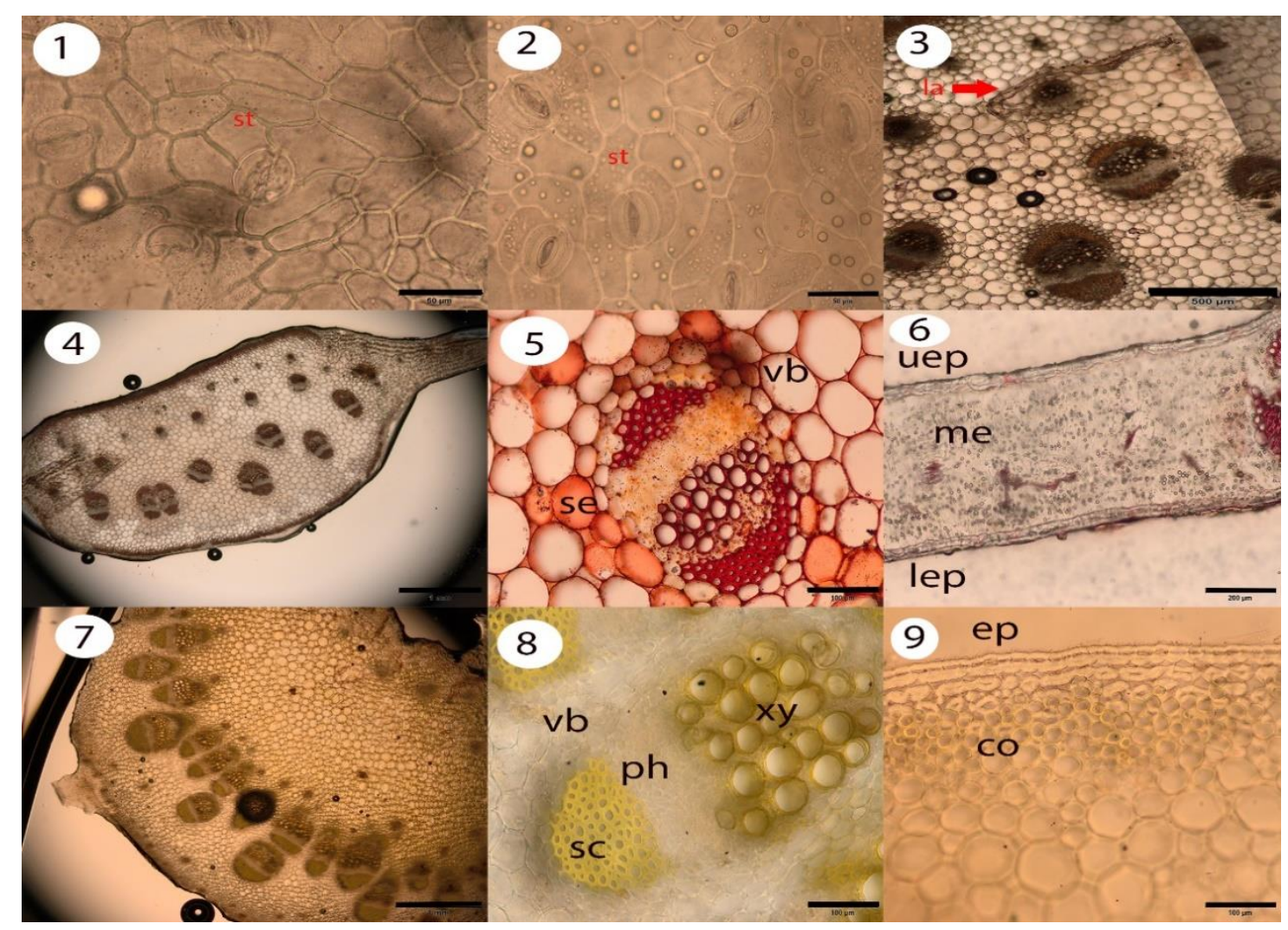

Figure 2. Anatomical structure of G. dersim. 1. Abaxial side of leaf, 2. Adaxial side of leaf, 3- Leaf midrib (arrow laticifer vessel), 4- Leaf midrib, 5- Leaf vascular bundle, 6 Leaf mesophyll, 7-Stem general view, 8-Stem vascular 
bundle, 9- Stem cortex view. ep: epidermis, co: cortex, la: laticifer, lep: lower epidermis, me: mesophyll, uep: upper epidermis, ph: phloem, sc: sclerenchyma, se: secreted substances, st: stomata, xy: xylem.

\section{Palynological results}

Pollen grains are radial symmetrical, isopolar, tricolporate. It is in the form of prolate-spheroidal and echinate ornamentation. Spines are clear, and ornamentation is perforate-faveolate. Polar axis length was measured as a mean of $42.56 \mu \mathrm{m}$ and equatorial axis as $38.08 \mu \mathrm{m}$ (Figure 3, Table 1).
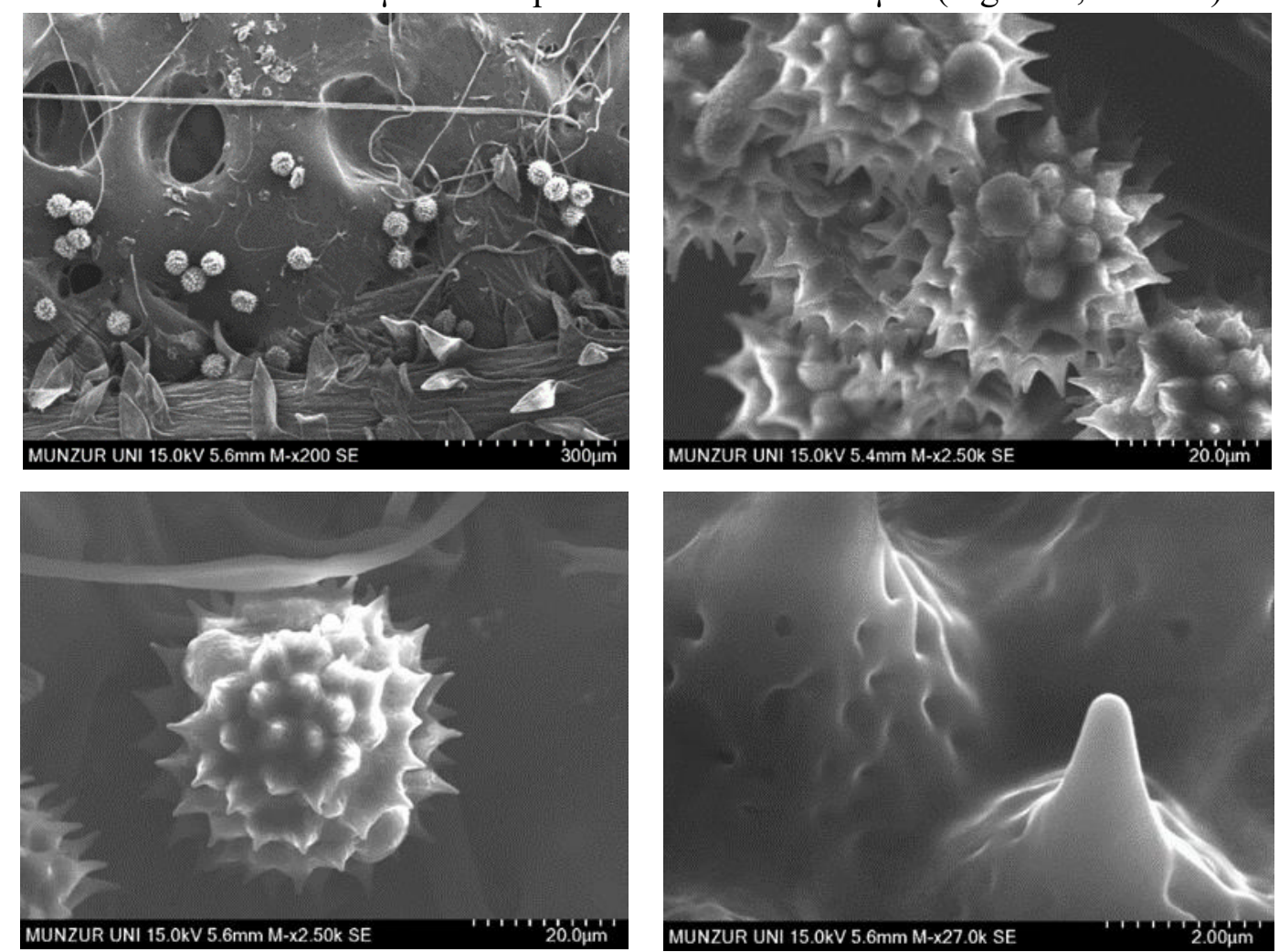

Figure 3. SEM photographs of pollen structure of G. dersim

Table 1. Pollen morphological features of G. dersim.

\begin{tabular}{lll}
\hline Pollen characteristics & \\
\hline Polar axis & Min-Max $(\mu \mathrm{m})$ & $38.379-45.782$ \\
\cline { 2 - 3 } & Mean $(\mu \mathrm{m})$ & 42.559 \\
\hline \multirow{2}{*}{ Equatorial axis } & Min-Max $(\mu \mathrm{m})$ & $32.493-42.121$ \\
\cline { 2 - 3 } & Mean $(\mu \mathrm{m})$ & 38.078 \\
\hline P/E & 1.12 \\
\hline Pollen shape & Prolate-spheroidal \\
\hline Aperture & Tricolporate \\
\hline Ornamentation & Echinate, perforate between spines \\
\hline
\end{tabular}

\section{Biochemical results}

In pigment analysis, Chl a content was measured as $3.91 \mu \mathrm{g} / \mathrm{g}$ in leaf and $0.63 \mu \mathrm{g} / \mathrm{g}$ in the stem. Chl b value was found to be $0.96 \mu \mathrm{g} / \mathrm{g}$ on the leaf and $0.14 \mu \mathrm{g} / \mathrm{g}$ on the stem. The content of Car (carotenoid) was determined as $1.07 \mu \mathrm{g} / \mathrm{g}$ on the leaf and $0.21 \mu \mathrm{g} / \mathrm{g}$ on the stem. Total Chl content was found to be $4.87 \mu \mathrm{g} / \mathrm{g}$ in leaf and $0.77 \mu \mathrm{g} / \mathrm{g}$ in the stem. While the total content of carbohydrates was $0.76 \mu \mathrm{g} / \mathrm{g}$ in the leaf, it was determined as $0.43 \mu \mathrm{g} / \mathrm{g}$ in the stem. According to the lipid peroxidation data, the malondialdehyde content in the leaf was measured as $1.26 \mu \mathrm{mol} \mathrm{MDA} / \mathrm{g} F W$ and $1.02 \mu \mathrm{mol}$ MDA / g FW in the stem. (Figure 4, Table 2). 


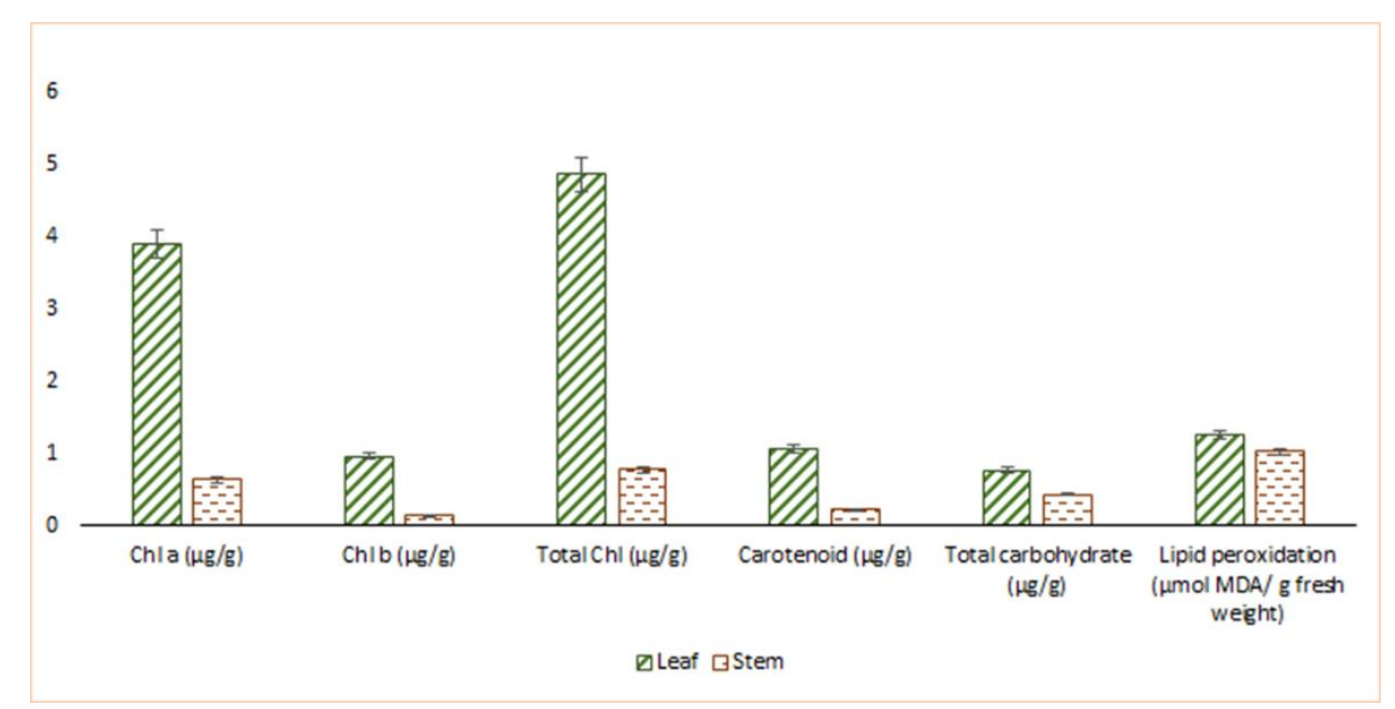

Figure 4. Pigment, total carbohydrate and lipid peroxidation data of leaf and stem in G. dersim

Table 2. G. dersim leaf and stem biochemical content

\begin{tabular}{lll}
\hline & Leaf & Stem \\
\hline Chl a $(\mu \mathrm{g} / \mathrm{g})$ & 3,91 & 0,63 \\
Chl b $(\mu \mathrm{g} / \mathrm{g})$ & 0,96 & 0,14 \\
Total Chl $(\mu \mathrm{g} / \mathrm{g})$ & 4,87 & 0,77 \\
Carotenoid $(\mu \mathrm{g} / \mathrm{g})$ & 1,07 & 0,21 \\
Total carbohydrate $(\mu \mathrm{g} / \mathrm{g})$ & 0,76 & 0,43 \\
Lipid peroxidation $(\mu \mathrm{mol} \mathrm{MDA} / \mathrm{g}$ fresh weight) & 1,26 & 1,02 \\
\hline
\end{tabular}

No previous detailed anatomical study on the genus Gundelia has been found. Therefore, the data in this study will be an essential database. If we look at the general anatomical features of the genus Gundelia, Solereder and Scott (1908) and Metcalfe and Chalk (1950) mentioned the existence of cortical vascular bundles and laticifer structures about the genus Gundelia. In our study, although rare, laticifer canals were found in the stem and leaf structure. Probably the laticifer uses latex fluid to cover wounds and protect the plant against herbivores and microorganisms (Fahn, 1990). So, milky secretion in laticifer channels has an important place in folk medicine. A study conducted on the genus Cirsium from the Asteraceae family stated that the leaf mesophyll structure was of the dorsiventral type. They stated that the anticlinal walls were flat, and 5 taxa were not flat in 21 taxa studied. They stated that the distribution area of these 21 taxa is at high altitude and in dry habitats. Besides, they stated that all taxa, except 3 taxa, were amphistomatic (Ozcan et al., 2015). In our study, the leaf of G. dersim is amphistomatic. However, the mesophyll type is unifacial. In the studies conducted by Metcalfe and Chalk (1950) and Kadereit and Jeffrey (2007), dorsiventral mesophyll was commonly found in the Asteraceae family. Again in G. dersim, it is gathered around 1100 meters and is a high-altitude area. Ozcan et al. leaf anticline walls were found to be flat in high altitude places (Ozcan et al., 2015). The leaf of G. dersim is also flat with anticlinal walls. Also, Sheidai et al. stated in their study that the leaf mesophyll type of Cirsium species in Iran is dorsiventral (Sheidai et al., 2018). It can be said that there is a significant difference between the Gundelia genus and the Cirsium genus of leaf mesophyll type. Also, Metcalfe and Chalk (1950) stated that the general stoma type of the Asteraceae family is an anomocytic (Ranunculaceae type) and anisocytic type. In G. dersim, anomocytic type and rarely anisocytic type stoma were also found. No trichome was found in the leaf and stem structure of G. dersim. It has been reported in previous studies that the pollen characteristics of the Asteraceae family have taxonomic significance (Tellería et al., 2013; Carrijo et al., 2013). Wodehouse (1930;1935) and Skvarla (1977), in 
their study, stated that the Asteraceae family pollen is echinate and generally tricolporate. It has the characteristics of the family with its pollen characteristics in G. dersim. Palynological studies can provide valuable data for a closely related genus. In studies on some Asteraceae species, echinate pattern structure has been described (Zafar et al., 2007; Ahmad et al., 2013). In this study, we investigated, it was determined that G. dersim taxon has echinate ornamentation. According to Wodehouse (1935), the spiny pollen (spinate) character is said to be a more primitive feature than spinless. Also, Wodehouse $(1926 ; 1928)$ stated that some Asteraceae species had fewer spins in wind-pollinated (anemophilous) and more spins in insect-pollinated (entomophilous). According to this information, it can be said that $G$. dersim is prone to pollination with insects. Wortley et al. investigated the pollen characteristics of $G$. tournefortii in their study (Wortley et al., 2007). Accordingly, they found that it was $48 \mu \mathrm{m}$ in diameter and tricolpate and echinate. In our study, we observed that these features of $G$. dersim are similar to $G$. tournefortii, but the diameter is approximately $38 \mu \mathrm{m}$, not $48 \mu \mathrm{m}$ (Figure 3 ).

Conducting biochemical analyses on plants provides indications about whether the plant is exposed to stress related to the ecological conditions in which it is located and how effective it can be in developing the environment in which it is located. It is also very important in terms of elucidating the resistance mechanisms in plants exposed to infection.

It is stated that the rate of photosynthesis is directly proportional to the content of light absorbed by chlorophyll. If the content of light absorbed by chlorophyll is high, the photosynthesis rate also increases (Kadığlu, 2016; Izzo et al., 2019).

Chlorophylls are the main pigments that give plants their characteristic green colour. Chlorophyll not only absorbs light, it transfers the energy obtained from one molecule to another and acts as a catalyst in photosynthetic reactions.

The two most important types of chlorophyll in terms of photosynthesis are chlorophyll a and chlorophyll $b$, while chlorophyll a initiates the light reaction of photosynthesis, while chlorophyll b plays a role as an auxiliary pigment in photosynthesis. Therefore, it is important to evaluate the two chlorophylls in terms of photosynthesis.

Chlorophylls are green-coloured pigments, and they have an essential role in photosynthesis. The change in chlorophyll content is important in determining the plant's response to stress factors (Cetin, 2017). In our study, Chl content was determined higher in both leaf and stem than Chl b. Total chlorophyll content was also determined more in the leaf (Figure 4). Carotenoids have many physiological functions. They effectively destroy free radicals and strengthen the immune system (Domonkos et al., 2013). In our study, the carotenoid content was determined higher in the leaf (Figure 4).

Carbohydrates modulate gene expression in plants and are significant sources of carbon and energy that serve as growth and development substrates. As a result, they serve as signalling molecules in a number of physiological processes (Granot et al. 2013). Carbohydrate metabolism has been described as a critical metabolic and transcriptional component that determines a plant's abiotic stress sensitivity (Li et al. 2015).

The functions of carbohydrates are not limited to being just energy stores. They are important building blocks of many structural materials of living organisms (Khowala et al., 2008). In this study, the total carbohydrate content was found higher in the leaf than the stem (Figure 4).

Lipid peroxidation is the oxidation of unsaturated fatty acids in the cell membrane and structure. The most important product of lipid peroxidation is malondialdehyde (MDA). There were studies in the 
literature showing that MDA content was increased in plants exposed to various stress conditions (Kaya, and Doganlar, 2016; Sun et al., 2019). In our study, MDA content was found higher in leaf than stem.

\section{CONCLUSION}

As a result of this study, a detailed anatomical study has been carried out for the first time on the genus Gundelia, a taxonomically complex genus. With the increasing number of species in recent years, each study on this genus will contribute significantly to the species taxonomic data.

As a result of this study, the anatomical and palynological structure and biochemical content of Gundelia dersim were revealed for the first time. Thus, it is thought that it will be the basis for future studies.

\section{Conflict of Interest}

The article authors declare that there is no conflict of interest between them.

\section{Author's Contributions}

The authors declare that they have contributed equally to the article.

\section{REFERENCES}

Afrasiabi AT, Zarei MA, 2019. Tyrosinase Inhibition, Antioxidant Activity and GC-MS Analysis of the Hexane Extracts of the Aerial Parts of Astragalus vegetus Bungi. and Gundelia turnifortii L., Journal of Medicinal Plants, 2(70): 73-86.

Ahmad M, Bano A, Zafar M, Khan MA, Chaudhry MJI, \& Sultana S, 2013. Pollen morphology of some species of the family Asteraceae from the alpine zone, Deosai Plateau, northern Pakistan, Palynology, 37(2): 189195.

Algan G, 1981. Bitkisel dokular için mikroteknik, Fırat Üniversitesi Fen Fakültesi, Bot- No:1, İstanbul.

Armağan M, 2016. Gundelia vitekii (Compositae), a new species from Turkey, Annalen des Naturhistorischen Museums in Wien. Serie B für Botanik und Zoologie, 129-134.

Çakılcıŏlu U, 2020. An ethnobotanical field study; traditional foods production and medicinal utilization of Gundelia L. species in Tunceli (Turkey), Indian Journal of Traditional Knowledge (IJTK), 19(4): 714-718.

Carrijo TT, Garbin ML, Leite WP, Mendonça CBF, Esteves RL, \& Gonçalves-Esteves V, 2013. Pollen morphology of some related genera of Vernonieae (Asteraceae) and its taxonomic significance, Plant systematics and evolution, 299(7): 1275-1283.

Cetin M, 2017. Change in Amount of Chlorophyll in Some Interior Ornamental Plants, Kastamonu University Journal of Engineering and Sciences 3(1):11-19.

Baytop A, 1972. Bitkisel Drogların Anatomik Yapısı. İstanbul Universitesi, Eczacılık Fakültesi, Yay. No. 829. İstanbul.

De-Kok L, Graham M, 1980. Levels of pigments, soluble proteins, amino acids and sulfhydryl compounds in foliar tissue of Arabidopsis thaliana during dark induced and natural senesence, Plant Physiology and Biochemistry, 27: 133-142.

Domonkos I, Kis M, Gombos Z, \& Ughy B, 2013. Carotenoids, versatile components of oxygenic photosynthesis, Progress in lipid research, 52(4): 539-561.

Fahn A, 1990. Plant Anatomy, Oxford: Pergamon Press.

Fırat M, 2013. Ferhenga Navên Riwekên Bi Kurdî/Kürtçe Bitki Adları Sözlüğü/Dictionary of Plant Names in Kurdish, Kalkan Ofset, Ankara.

Firat M, 2016a. Four new species of Gundelia L. (Asteraceae) from Anatolia: G. komagenensis, G. colemerikensis, G. cilicica and G. anatolica, Vameda Ofset Press, Van.

Firat M, 2016b. Iris koyuncui (Iridaceae), a new species from Hakkâri province (Turkey) belonging to subgenus Scorpiris, Phytotaxa, 263: 51-57. https://doi.org /10.11646/phytotaxa.263.1.5. 
Firat M, 2017a. Gundelia mesopotamica (Asteraceae), a new lactiferous species from Mardin (Turkey), Acta Biologica Turcica, 30(3): 64-69.

Firat M, 2017b. Gundelia rosea (Asteraceae), a new record for the Flora of Turkey with contributions to its systematics, Acta Biologica Turcica, 30(2): 31-35.

Firat M, 2017c. The resurrection and a new status of Gundelia tournefortii L. var. asperrima Trautv. (Asteraceae), OT Sistematik Botanik Dergisi, 24(2): 57-67.

Firat M, 2018a. Gundelia armeniaca (Asteraceae), a species new to the flora of Turkey, with contributions to its taxonomy, Communications Faculty of Sciences University of Ankara Series C, 27(2): 35-46.

Firat M, 2018b. A new status of Gundelia tournefortii L. forma purpurascens Bornm. (Asteraceae) and a new record for the flora of Turkey, OT Sistematik Botanik Dergisi, 25(1): 11-24.

Firat M, 2019a. Gundelia siirtica (Asteraceae), a new lactiferous species from Siirt (south-eastern Anatolia), Phytotaxa, 394(4): 276-284.

Firat M, 2019b. New status of Gundelia tournefortii L. var. armata Freyn \& Sint. (Asteraceae), and a new synonym of its, OT Sistematik Botanik Dergisi, 26(1): 17-32.

Firat M, 2021a. A new taxonomic arrangement of the Asian genus Gundelia (Asteraceae), including two subgenera and two sections, Acta Biologica Turcica, 34(2): 92- 99.

Firat M, 2021b. Gundelia cappadocica (Asteraceae); a new lactiferous species from Cappadocia (Kapadokya) Turkey, belonging to G. subg. Gundelia sect. Komagenenses, Acta Biologica Turcica, 34(3): 120-131.

Funk VA, Bayer RJ, Keeley S, Chan R, Watson L, Gemeinholzer B, ... \& Jansen RK, 2005. Everywhere but Antarctica: using a supertree to understand the diversity and distribution of the Compositae, Biologiske skrifter, 55: 343-374.

Genç İ., Fırat M. 2019. Karyological study of the genus Gundelia (Compositae) in Turkey, Caryologia 72(1): 4553. doi: 10.13128/cayologia-250.

Granot D, David-Schwartz R, Kelly G, 2013. Hexose kinases and their role in sugar sensing and plant development. Frontiers in Plant Science 4: 44.

Heath RL, Packer L, 1968. Photoperoxidation in isolated chloroplasts: I. Kinetics and stoichiometry of fatty acid peroxidation, Archives of biochemistry and biophysics, 125(1): 189-198.

Izzo LG, Arenab C, De Miccoa V, Capozzia F, Aronnea G, 2019. Light quality shapes morpho-functional traits and pigment content of green and red leaf cultivars of Atriplex hortensis, Scientia Horticulturae. 246: 942950.

Kadereit JW, Jeffrey C, 2007. Flowering plants. Eudicots. In: Kubitzki K (ed) The families and genera of vascular plants, vol 8. Springer-Verlag, Berlin, Heidelberg, pp: 60-64.

Kadıŏglu A, 2016. Bitki fizyolojisi, Akademik Baskı, Trabzon, Türkiye.

Karaaslan Ö, Çöteli E, Karataş F, 2014. Investigation of Amounts of A, E, C Vitamins with Malondialdehyde and Glutathione in Plant Gundelia tournefortii, Erzincan Üniversitesi Fen Bilimleri Enstitüsü Dergisi Cilt-Say1: 7(2):159-168.

Kaya A, Doganlar ZB, 2016. Exogenous jasmonic acid induces stress tolerance in tobacco (Nicotiana tabacum) exposed to imazapic, Ecotoxicology and Environmental Safety 124:470-479.

Khowala S, Verma D, \& Banik SP, 2008. Biomolecules:(Introduction, Structure \& Function), Drug Dev Biotechnol Indian Inst Chem Biol, 2-93.

Konak M, Ateș M, Șahan Y, 2017. Evaluation of antioxidant properties of Gundelia tournefortii: a wild edible plant, Ziraat Fakültesi Dergisi, Uludağ Üniversitesi, 31(2): 101-108.

Kupicha FK, 1975. Gundelia. In: Davis, P.H. (Ed.) Flora of Turkey, vol. 5. University Press, Edinburgh, pp: 325326.

Li X, Lawas LMF, Malo R et al., 2015. Metabolic and transcriptomic signatures of rice floral organs reveal sugar starvation as a factor in reproductive failure under heat and drought stress. Plant, Cell \& Environment 38: 2171-2192. 
Lichtenthaler K, Welburn AR, 1983. Determination of total carotenoids and chlorophylls a and b of leaf extracts in different solvents, Biochem Society Transactions, 11: 591-592.

Metcalfe CR, Chalk L, 1950. Anatomy of the Dicotyledons, vol. 2, $1500 \mathrm{p}$.

Nersesyan A, 2014. Gundelia armeniaca Nersesyan (Compositae), a new species from Armenia, Annalen des Naturhistorischen Museums Wien Serie B, 116: 191-196.

Ozcan M, Demiralay M, \& Kahriman A, 2015. Leaf anatomical notes on Cirsium Miller (Asteraceae, Carduoideae) from Turkey, Plant systematics and evolution, 301(8): 1995-2012.

Punt W, Hoen PP, Blackmore S, Nilsson S, Le Thomas A, 2007. Glossary of Pollen and Spore Terminology, Review of Palaeobotany and Palynology, 143: 1-81.

Rosenberg S, 1980. Physiological studies of lignocellulose degratation by thermotolerant mold Chrysosprorium prunosum, Symposium on the biological transformation of lignocellulose, 12: 133-142.

Sheidai M, Shojaei S and Koohdar F, 2018. Anatomy study of the genus Cirsium Mill. in Iran, Acta Biologica Szegediensis, 62(1), pp: 37-43. doi: 10.14232/abs.2018.1.37-43.

Skvarla JJ, 1977. Pollen morphology in the Compositae and in morphologically related families, The biology and chemistry of the Compositae, 141-248.

Solereder H, Scott DH, 1908. Systematic anatomy of the dicotyledons: a handbook for laboratories of pure and applied botany (Vol. 2), Clarendon Press.

Sun G, Xu X, Xiao Y, Wei X, Wang Y, \& Tang Y, 2019. Effects of hyperaccumulator plant straw on antioxidant enzyme activities and osmotic substances and malondialdehyde content of lettuce under cadmium stress, In E3S Web of Conferences (Vol. 136, p. 07004), EDP Sciences.

Tarikahya Hacioğlu B., Fırat M. 2017. ITS Phylogeny and Molecular Dating of some Gundelia (Asteraceae) of Anatolia. Anadolu 27 (2): 74-77.

Tellería MC, Sancho G, Funk VA, Ventosa I, \& Roque N, 2013. Pollen morphology and its taxonomic significance in the tribe Gochnatieae (Compositae, Gochnatioideae), Plant Systematics and Evolution, 299(5): 935-948.

Vitek E, Fayvush G, Tamanyan K, Gemeinholzer B, 2010. New taxa of Gundelia (Compositae) in Armenia, Annalen des Naturhistorischen Museums Wien Serie B, 111: 85-99.

Vitek E, Noroozi J, 2017. Gundelia tehranica (Compositae), a new species from Iran, Annalen des Naturhistorischen Museums Wien Serie B, 119: 243-248.

Vitek E, Yüce E, Ergin C, 2014. Gundelia dersim and Gundelia munzuriensis (Compositae), two new species from Turkey, Phytotaxa, 161(2):130-138.

Wodehouse RP, 1926. Pollen grain morphology in the classification of the Anthemideae, Bulletin of the Torrey Botanical Club, 479-485.

Wodehouse RP, 1928. The phylogenetic value of pollen-grain characters, Annals of Botany, 42(168): 891-934.

Wodehouse RP, 1930. Pollen Grains in the Identification and Classification of Plants. V. Haplopappus and Other Astereae: The Origin of the Furrow Configurations, Bulletin of the Torrey Botanical Club, 21-46.

Wodehouse RP, 1935. Pollen grains. Their structure, identification and significance in science and medicine, Published by McGraw Hill. New York.

Wortley AH, Funk VA, Robinson H, Skvarla JJ, Blackmore S, 2007. A search for pollen morphological synapomorphies to classify rogue genera in Compositae (Asteraceae), Review of Palaeobotany and Palynology, 146(1-4): 169-181.

Zafar M, Ahmad M, Khan MA, 2007. Palynology of family Asteraceae from Flora of Rawalpindi-Pakistan, International Journal of Agriculture and Biology. 9: 156-161. 